J. Natn. Sci. Coun. Sri Lanka $199220(1): 127-131$

SHORT COMMUNICATION

\title{
THE EFFECT OF SALINE MEDIA OF VARYING IONIC COMPOSITION ON STOMATAL RESISTANCE OF RICE (Oryza säiva L.) LEAVES
}

\section{B.D. Peiris}

Department of Botany, University of Kelaniya, Kelaniya.

(Date of receipt $\quad \therefore 23$ January 1992)

(Date of acceptance : 08 July 1992)

\section{Introduction}

Increased stomatal resistance due to water and salt stress reduce transpiration. ${ }^{1-4}$ The sensitivity of stomata to decreased leaf water potentials varies between species and is influenced by age, growth condition of the plant ${ }^{3,5,6}$ and the age of the leaf. Accumulation of abscisic acid (ABA) as a result of water and salt stress is the cause of stomatal closure. . $^{2,5,8}$ Although salt stress may lead to stomatal closure, and therefore, to decreased transpiration, if salt is allowed to enter guard cells, it may reverse the osmotic gradient leading to stomatal opening and therefore increased transpiration.' Earlier studies, especially on rice, have generally used single salts to create saline environments. When salt mixtures were used, their composition did not mimic natural salinity types. ${ }^{11-12}$ The objective of this study was to observe stomatal responses of rice leaves to salt mixtures with compositions similar to those in saline soils.

\section{Materials and Methods}

\section{Plant material and seed germination}

A salt sensitive variety, IR5929-12-3 (IR5929) (acc.no. 57016) and a salt tolerant variety, Pokkali (acc. no. 26869) of rice (Oryza sativa L.) were used. Seeds were surface sterilized by immersion for one minute with $0.1 \%$ mercuric chloride solution, and then washed with several changes of demineralized water. The seeds were soaked for 24 hours in demineralized water, and then spread on a moist filter paper in Petri dishes for germination.

\section{Plant growth and salinization}

Three days later seedlings were transferred to $3 l$ plastic pots filled with culture solution ${ }^{10}$ (Table 1) and placed in a greenhouse. Seedling density was three per pot. The medium was salinized with one of three types of ionic composition, Chloride Sulphate (CS) (with sulphate dominance), Sulphate Chloride (SC) (with Chloride dominance) and Chloride (C) when the seedlings were two weeks old. These three 
compositions represented natural saline soil types. ${ }^{11,12}$ The three types of ionic composition were prepared using the ionic ratios given by Strogonov $(1964)^{12}$ (Table 2).

Table 1: Composition of the culture solution.

\begin{tabular}{lccc}
\hline Compound & mmol/liter & Compound & $\mu$ mol/liter \\
\hline $\mathrm{CaCl}_{2}$ & 2 & $\mathrm{FeEDTA}$ & 100 \\
$\mathrm{MgSO}_{4}$ & 2 & $\mathrm{H}_{3} \mathrm{PO}_{3}$ & 25 \\
$\mathrm{KCl}$ & 2 & $\mathrm{MnSO}_{4}$ & 5 \\
$\mathrm{~K}_{2} \mathrm{SO}_{4}$ & 1 & $\mathrm{ZnSO}_{4}$ & 2 \\
$\mathrm{NH}_{4} \mathrm{NO}_{3}$ & $\mathrm{CuSO}_{4}$ & 0.5 \\
$\mathrm{NH}_{4} \mathrm{H}_{2} \mathrm{PO}_{4}$ & 2 & $\left(\mathrm{NH}_{4}\right)_{6} \cdot \mathrm{Mo}_{7} \mathrm{O}_{24}$ & 0.1 \\
\hline
\end{tabular}

In each type four different levels of salinity (expressed as electrical conductance) 2, 4, 6 and $8 \mathrm{dS} / \mathrm{m}$ were used. Electrical conductance of the control (growth medium alone) varied from 1.0 to $1.1 \mathrm{dS} / \mathrm{m}$. Electrical conductance $=0$ indicates the nor salinized control.

\section{Measurement of stomatal resistance}

Fifty days after salinization, stomatal resistance was measured on the abaxial epidermis of the first recently matured leaf of the main tiller using LI-700 Transien Porometer.

\section{Statistical analysis}

Each value reported for stomatal resistance was the mean of 9 plants. A test of significance for differences between the treatments was provided by Tukey multiple range test at $\mathbf{P}=0.05$. Coefficient of variation was $10 \%$.

\section{Results}

The stomatal resistance of the leaves of Pokkali plants grown in SC and CS media increased with increasing salinity. However, in $\mathrm{C}$ medium stomatal resistance increased only up to $2 \mathrm{dS} / \mathrm{m}$ and then declined (Table 3 ).

The stomatal resistance of salt sensitive IR5929 plants grown in CS medium increased up to $6 \mathrm{dS} / \mathrm{m}$ and then declined at a salinity of $8 \mathrm{dS} / \mathrm{m}$. In the other 2 saline media stomatal resistance increased only up to $4 \mathrm{dS} / \mathrm{m}$ and then declined. IR 5929 plants grown in $\mathrm{C}$ medium at $8 \mathrm{dS} / \mathrm{m}$ salinity however did not survive (Table 3 ). 
Table 2. Ion composition $\left(\mathrm{g} \mathrm{dm}^{-3}\right)$ of the salt mixtures

\begin{tabular}{|c|c|c|c|c|}
\hline \multirow{2}{*}{$\begin{array}{l}\text { Ionic } \\
\text { composition }\end{array}$} & \multicolumn{4}{|c|}{ Electrical Conductance $\left(\mathrm{dS} \mathrm{m} \mathrm{m}^{-1}\right)$} \\
\hline & 2 & 4 & 6 & 8 \\
\hline
\end{tabular}

Chloride (C)

$\mathrm{Na}^{+}$
$\mathrm{K}^{+}$
$\mathrm{Mg}^{2+}$
$\mathrm{Ca}^{2+}$
$\mathrm{SO}_{4}^{2-}$
$\mathrm{Cl}^{-}$
$\mathrm{HCO}_{3}^{-}$

$\begin{array}{lcll}0.295 & 0.688 & 1.081 & 1.495 \\ 0.008 & 0.020 & 0.031 & 0.043 \\ 0.035 & 0.083 & 0.131 & 0.181 \\ 0.010 & 0.025 & 0.040 & 0.055 \\ 0.054 & 0.165 & 0.260 & 0.360 \\ 0.532 & 1.242 & 1.951 & 2.697 \\ 0.004 & 0.013 & 0.021 & 0.030\end{array}$

Sulphate-chloride (SC)

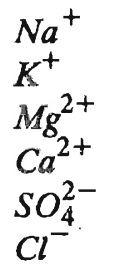

$\begin{array}{llll}0.235 & 0.540 & 0.864 & 1.172 \\ 0.009 & 0.027 & 0.045 & 0.064 \\ 0.061 & 0.147 & 0.235 & 0.319 \\ 0.011 & 0.026 & 0.047 & 0.064 \\ 0.250 & 0.583 & 0.930 & 1.264 \\ 0.392 & 0.912 & 1.461 & 1.981\end{array}$

Cloride-sulphate (CS)

\begin{tabular}{lllrl}
$\mathrm{Na}^{+}$ & 0.090 & 0.211 & 0.331 & 0.445 \\
$\mathrm{~K}^{+}$ & 0.011 & 0.029 & 0.045 & 0.062 \\
$\mathrm{Mg}^{2+}$ & 0.144 & 0.334 & 0.52 & 0.704 \\
$\mathrm{Ca}^{2+}$ & 0.005 & 0.014 & 0.02 & 0.031 \\
$\mathrm{SO}_{4}^{2-}$ & 0.701 & 1.617 & 2.532 & 3.401 \\
$\mathrm{Cl}^{-}$ & 0.070 & 0.161 & 0.255 & 0.342 \\
\hline
\end{tabular}

\section{Discussion}

Water stress stimulates ABA accumulation which leads to stomatal closure. ${ }^{2-4}$ Mizrahi et $a l^{8}$ and $\mathrm{Tal}^{13}$ report that salinity promotes the synthesis of $\mathrm{ABA}$. Therefore, the increasing stomatal resistance with increasing salinity observed in the current study might be due to the accumulation of $\mathrm{ABA}$. 
Table 3 : Effect of varying the ionic composition on stomatal resistance of rice

\begin{tabular}{llll}
\hline $\begin{array}{l}\text { Salinity } \\
\text { type }\end{array}$ & $\begin{array}{c}\text { EC } \\
\mathrm{ds} \mathrm{m}^{-1}\end{array}$ & \multicolumn{2}{c}{ Stomatal resistance $\left(\mathrm{s} \mathrm{cm}^{-1}\right)$} \\
\cline { 2 - 4 } & & Pokkali & IR5929 \\
\hline Control & 0 & $1.76 \mathrm{i}$ & $1.58 \mathrm{e}$ \\
CS & 2 & $1.88 \mathrm{gh}$ & $1.92 \mathrm{bc}$ \\
& 4 & $2.00 \mathrm{ef}$ & $1.98 \mathrm{ab}$ \\
& 6 & $2.02 \mathrm{e}$ & $2.09 \mathrm{a}$ \\
& 8 & $2.16 \mathrm{~d}$ & $1.92 \mathrm{bc}$ \\
SC & 2 & $2.05 \mathrm{e}$ & $1.91 \mathrm{bcd}$ \\
& 4 & $2.26 \mathrm{c}$ & 1.96 \\
& 6 & $2.50 \mathrm{~b}$ & $1.83 \mathrm{~cd}$ \\
& 8 & $2.71 \mathrm{a}$ & $1.80 \mathrm{~d}$ \\
$\mathrm{C}$ & 2 & $2.10 \mathrm{de}$ & $1.68 \mathrm{e}$ \\
& 4 & $1.90 \mathrm{fg}$ & $1.69 \mathrm{e}$ \\
& 6 & $1.80 \mathrm{hi}$ & $1.59 \mathrm{e}$ \\
& 8 & $1.84 \mathrm{ghi}$ & - \\
\hline
\end{tabular}

Values within a column followed by the same letter are not significantly different.

Decreased stomatal resistance at high salinity (Table 2 ) was also observed in the current study. This may be due to salt entering guard cells, at high salinity $(6,8 \mathrm{ds} / \mathrm{m})$ and reversing the osmotic gradient resulting in to stomatal opening as suggested by Sen and Chawan. ${ }^{9}$

\section{References}

1. Beadle C.I., Stevenson K.R., Neumann H.N., Thurtell G.W. \& King K.M. (1973). Diffusive resistance, transpiration and photosynthesis in single leaves of corn and sorghum in relation to leaf water potential. Canadian Journal of Plant Science 53: $537-544$.

2. Gorham J., Wyn jones R.G. \& Mcdonnell E. (1985). Some mechanisms of salt tolerance in crop plants. Plant and Soil 89: 15 - 40.

3. Mccree K.J. (1974). Changes in the stomatal response characteristics of grain sorghum produced by water stress during growth. Crop Science 14: 273 - 278.

4. Zieger E. (1983). The biology of stomatal guard cells. Annual Review of Plant Physiology 34: 441 - 475. 
5. Avies W.J. (1977). Stomatal responses to water stress and light in plants grown in controlled environments and in the field. Crop Science 17: 735 - 740.

6. Jordan W.R. \& Ritchie J.T. (1971). Influence of soil water stress on evaporation, root absorption and internal water status of cotton. Plant Physiology 48: 783 788.

7. Hoffman G.J., Shalhevet J. \& Meiri A. (1980). Leaf age and salinity influence water relations of pepper leaves. Physiologia Plantarum 48: 463 - 469.

8. Mizrahi Y., Blumenfeld A. \& Richmond A.E. (1970). Abscisic acid and transpiration in leaves in relation to osmotic root stress. Plant Physiology 46: 169 . 171.

9. Sen D.N. \& Chawan D.D. (1975). Role of Abscisic acid in the closure of stomata in some arid zone plant species. Biologia Plantanum 17: 198 - 201.

10. Bower C. A. \& Tamimi Y.N. (1979). Root adjustment associated with salt tolerance in small grains. Agronomy Joumal 71: $690-693$.

11. FAO/UNESCO (1973). Irrigation, drainage and salinity. An International source book. London, pp. $69-79$.

12. Strogonov B.P. (1964). Physiological basis of salt tolerance of plants, Daniel Davey \& Co. Inc., New York.

13. Tal M. (1977). Physiology and polyploid : DNA, RNA, Protein and Abscisic acid in auto tetraploid and diploid tomato under low and high salinity. Botanical Gazatte 138: 119 - 122. 